\title{
The Twilight War: The Secret History of America's Thirty-Year Conflict with Iran
}

\author{
David Crist \\ Penguin, New York, 2012, \$36.00/£20.69, ISBN-10: 1594203415
}

International Politics Reviews (2014) 2, 84. doi:10.1057/ipr.2014.20

\section{DB Des Roches}

Near East South Center for Strategic Studies, National Defense University, Washington DC.

The enmity between Iran and the United States since 1979 has evolved beyond the range of metaphorical description. The Iranians have played chess, while the Americans have played checkers; the Iranians have played poker while the Americans played bridge; the Americans have all the watches but the Iranians have the time. The one constant is that the United States and Iran have been willing to resort to a degree of military action in order to advance their security goals at the expense of the other nation.

Lately, we've seen an extremely unusual harmony of interests where the American government and the Iranian government are simultaneously supporting the corrupt and feckless Iraqi government against the resurgent and mutually detested Islamic State of Iraq and al-Sham.

The history of the conflict between Iran and the United States is fraught with emotion, subterfuge and deceit. Laying this out in a style that is both comprehensive and readable is a challenge David Crist answers in The Twilight War.

Crist brings two advantages to his account of the confrontation between Iran and the United States. The first is that he is a world-class historian, who has worked at the US Army Center for Military History and is now working as a historian of the Joint Chiefs of Staff. The second is he is the son of General George Crist, the commander of US Central Command during the Tanker War and some of the other events covered in the book.
Crist's perspective makes for a book that is comprehensive and interesting to read. He draws on interviews with key US participants, and makes use of journals and letters not in public collections. He has also conducted intensive archival research to ensure his account is as complete as current sources allow.

The book's thesis is the United States has been in a long and undeclared war with Iran since the 1979 revolution. Some incidents - such as the embassy hostage taking and mining of the Gulf and American actions against Iranian forces doing so - were conducted by the government. Others - such as the bombing of the US facilities in Beirut, the US support for Saddam Hussein against Iran and the Iranian campaign against US troops in Iraq - were conducted by proxies under Iranian Revolutionary Guard direction. There is a long and helpful account of the internal American debate over escorting tankers in the Gulf as well as of the arms-for-hostages swaps which marred the Reagan administration.

Crist's book is comprehensive and informative but certainly not bloodless. At times, one gets the sense that there are scores being settled, as when one American admiral is introduces as a 'colorless toady' and then not discussed again.

Crist's account provides enough footnotes and references for scholars, while still being a good read for armchair generals. As we ponder the future of the Iranian nuclear negotiations, analysts will be well-served to spend an evening or two with Crist's brisk prose to review how we got to where we are. 